\title{
EXTENDING THE RIGHT TO LIFE UNDER THE INTERNATIONAL COVENANT ON CIVIL AND POLITICAL RIGHTS: GENERAL COMMENT 36
}

\author{
Sarah Joseph*
}

\begin{abstract}
The UN Human Rights Committee (HRC), which monitors and supervises the implementation by States parties of the International Covenant on Civil and Political Rights (ICCPR), issued General Comment 36 in October 2018. The General Comment clarifies and expands upon the HRC's previous interpretations of Article 6, the guarantee of the right to life in the ICCPR. In this article, those areas where the General Comment extends the HRC's previous jurisprudence will be explained. The following issues are addressed: the right to life and law enforcement, abortion, voluntary dying, the positive right to life including socioeconomic aspects thereof, the death penalty, and the relationship between Article 6 and other international legal regimes such as international humanitarian law.
\end{abstract}

KEYWORDS: right to life, General Comment 36, ICCPR, Article 6, Human Rights Committee.

The following commentary analyses General Comment 36 on the right to life in Article 6 of the International Covenant on Civil and Political Rights (ICCPR), ${ }^{1}$ which was adopted by the treaty's monitoring body, the Human Rights Committee (HRC) in October 2018. ${ }^{2}$

General Comment 36 replaces two earlier General Comments, General Comment 6 $(1982)^{3}$ and 14 (1984). ${ }^{4}$ The earlier General Comment was typical of the HRC's earliest General Comments, in that it added little beyond the obvious to the actual text of the right. General Comment 14 specifically targeted the waging of war and the possession of nuclear weapons.

General Comment 36 has been developed over four years, with extensive opportunities for feedback from States, other UN institutions, national human rights institutions, academics and civil society. ${ }^{5}$ It manifests a new approach to General Comments in that the HRC clearly goes far beyond its own jurisprudence in explaining the scope of the right. In contrast to the

\footnotetext{
* Sarah Joseph is a Professor of Law and the Director of the Castan Centre for Human Rights Law at Monash University, Melbourne.

${ }^{1}$ International Covenant on Civil and Political Rights 1966, 999 UNTS 171.

2 Human Rights Committee, General Comment no 36 (2018) on Article 6 of the International Covenant on Civil and Political Rights, on the right to life (General Comment 36), 30 October 2018.

${ }^{3}$ Human Rights Committee, General Comment 6 (1982).

${ }^{4}$ Human Rights Committee, General Comment 14 (1984).

${ }^{5}$ See the list of submissions in 2017 at https://www.ohchr.org/en/hrbodies/ccpr/pages/gc36article6righttolife.aspx [last accessed 29 January 2019].
} 
earlier General Comments, the extensively footnoted document is 24 pages long, as opposed to the bare one and a half pages in General Comment 6.

Below, the major points of interest within the General Comment are discussed, with an emphasis on those areas where it goes beyond the HRC's prior jurisprudence, and where it clarifies the composite outcome of disparate prior statements. Areas of continued uncertainty are also identified. For example, the General Comment adds considerably or consolidates prior jurisprudence on abortion and voluntary dying, hence these topics are addressed in detail below. In contrast, the commentary in the General Comment on the need for and required character of investigations of deaths at the hands of the State, the right's nonderogable status, the incompatibility of reservations thereto, and on the relationship between refoulement and amnesties with the right to life, is not addressed in detail below. While all of those topics are important, the General Comment does not add much of significance to the HRC's prior jurisprudence on those topics.

This article concludes with a summary of the major extensions to Article 6 jurisprudence arising from General Comment 36, as well as on the key questions remaining regarding the scope of Article 6. The expansive methodology evinced in the drafting on this new General Comment is also noted, and welcomed.

\section{ARTICLE 6 (1): THE GENERAL GUARANTEE}

Article 6(1) contains the general guarantee of the right, and reads:

Every human being has the inherent right to life. This right shall be protected by law. No one shall be arbitrarily deprived of his life.

At paragraph 3 of General Comment 36, the HRC states that the right must "not be interpreted narrowly". In that regard, it concerns:

the entitlement of all individuals to be free from acts and omissions that are intended or may be expected to cause their unnatural or premature death, as well as to enjoy a life with dignity.

Much of the General Comment is spent fleshing out the means by which States parties to the ICCPR are required to protect people's lives from acts and omissions, whether they emanate from the State or another actor. As explained below, threats to life can also arise from general societal conditions. The intriguing separate reference to enjoying "a life with dignity" is paid comparatively little attention, and is discussed further below.

At paragraph 63, the HRC confirms the territorial scope of Article 6. States parties have extraterritorial obligations under Article 6 with regard to external territories under their effective control, and over "all persons over whose enjoyment of the right to life it exercises power or effective control". It adds:

This includes persons located outside any territory effectively controlled by the State, whose right to life is nonetheless impacted by its military or other activities in a direct and reasonably foreseeable manner. 
Here, the HRC manifests a clear difference between the application of the rights to life under, respectively, the ICCPR and the European Convention on Human Rights (ECHR). ${ }^{6}$ Under the latter treaty, it seems that a State's extraterritorial obligations do not necessarily extend to the use of lethal force against persons if those persons were not under the State's prior physical control. ${ }^{7}$ In contrast, the HRC clearly states that such instances do come within Article 6 of the ICCPR.

\section{A. Law Enforcement}

The right to life is not absolute. One can be deprived of one's life in circumstances that are not arbitrary. In certain circumstances, a person can be killed due to the threat, or perceived threat, that that person poses to the life of another, or the lives of others. In paragraph 12, the HRC addresses the circumstances in which a private individual or a law enforcement officer may use lethal force. In regard to the latter, the HRC states:

The use of potentially lethal force for law enforcement purposes is an extreme measure, which should be resorted to only when strictly necessary in order to protect life or prevent serious injury from an imminent threat. It cannot be used, for example, in order to prevent the escape from custody of a suspected criminal or a convict who does not pose a serious and imminent threat to the lives or bodily integrity of others. The intentional taking of life by any means is permissible only if it is strictly necessary in order to protect life from an imminent threat.

Before addressing the normative content of this paragraph, its language must be remarked upon. In particular, the HRC opens by saying that the use of potentially lethal force "should" only be resorted to in very limited circumstances. The use of the word "should" might indicate that this guidance is recommendatory only, rather than an indication of what the HRC believes to be the scope of the Article 6 obligation. ${ }^{8}$ However, the "should" of the first sentence is followed by stronger language in the form of "cannot" in the second, which indicates the HRC's assertion of an actual obligation. The third sentence, in its use of "permissible only ..." confirms that assertion. This language mismatch, in particular the unfortunate use of the word "should", occurs several times in the General Comment, as further noted, where relevant, below.

The application of Article 6 to law enforcement action has evolved considerably from the early Optional Protocol decision in Suarez de Guerrero v Colombia, decided in $1982 .{ }^{9}$ In that case, the HRC indicated that lethal force could be used to "effect the arrest or prevent the

\footnotetext{
${ }^{6}$ European Convention on Human Rights (1950) ETS 5

${ }^{7}$ See Al-Saadoon v Secretary of State for Defence [2016] EWCA Civ 811, interpreting the ECHR law on this point. Such killings would come within a State's jurisdiction if it arose in territory over which it exercised effective control, or in territory over which it exercised public powers. See Joseph and Dipnall 'Scope of Application', in Moeckli, Shah and Sivakumaran (eds), International Human Rights Law, $3^{\text {rd }}$ edn, (2017), 110 at 123.

${ }^{8}$ The HRC is a non-judicial body so its findings are authoritative interpretations of the obligations in the ICCPR, rather than legally binding of themselves.

${ }^{9}$ Suarez de Guerrero v Colombia, Views, R.11/45, U.N. Doc. Supp. No. 40 (A/37/40) at 137 (1982).
} 
escape" of a person at paragraph 13.2. ${ }^{10}$ The HRC was reflecting the actual words of exceptions to the right to life in Article 2 of the ECHR. The interpretation of Article 6 has evolved to the point that lethal force can only be used against a person who poses a lethal threat, or a threat to bodily integrity. ${ }^{11}$

Two issues remain unclarified in the General Comment. Firstly, it is possible for a lethal threat to be mistakenly but reasonably perceived. This circumstance is not clearly included as an exception to the right to life in General Comment 36, though it seems likely that it would constitute an exception. ${ }^{12}$

Second, each scenario outlined by the HRC requires that the threat posed by the person against whom force is to be used be "imminent". In this respect, the HRC seems to extend Article 6 obligations beyond those outlined in the United Nations Basic Principles on the Use of Force and Firearms by Law Enforcement Officials $1990 .{ }^{13}$ Principle 9 thereof states:

Law enforcement officials shall not use firearms against persons except in selfdefence or defence of others against the imminent threat of death or serious injury, to prevent the perpetration of a particularly serious crime involving grave threat to life, to arrest a person presenting such a danger and resisting their authority, or to prevent his or her escape, and only when less extreme means are insufficient to achieve these objectives. In any event, intentional lethal use of firearms may only be made when strictly unavoidable in order to protect life.

As can be seen, the need for an "imminent" threat under Principle 9 only arises with regard to shooting in self-defence or the defence of others. It does not explicitly relate to the use of lethal force to prevent a crime involving a grave threat to life, or to effect the arrest of or the escape of a person who poses such a threat. General Comment 36 explicitly extends the need for "imminence" to all scenarios.

What is an "imminent" threat? Clearly, the threat must concern a likelihood arising in the near future, but how close must that near future be? For example, an armed terrorist with hostages clearly poses an imminent threat to the lives of the hostages. However, if that terrorist is clearly disarmed and somehow escapes, is it permissible for the police to use potentially lethal force if that is the only way to prevent escape, given that it is probably reasonable to assume that the escapee continues to harbour deadly terroristic intentions? It is submitted that many police forces in the world, particularly those involved in counterterrorism operations, would use potentially lethal force in that instance. ${ }^{14}$

\footnotetext{
10 These circumstances were not relevant on the facts of the case, so the apparent breadth of the power to use lethal force was not at issue.

11 The same evolution has occurred under Article 2 of the ECHR. See McCann and Others v UK, 18984/91, Merits, 27 September 1995.

12 The mistaken but reasonable use of lethal force has been accepted, for example, by the European Court of Human Rights in McCann et al v UK 18984/91, Merits 27 September 1995.

${ }^{13}$ United Nations Basic Principles on the Use of Force and Firearms by Law Enforcement Officials 1990, adopted by the Eighth United Nations Congress on the Prevention of Crime and the Treatment of Offenders, Havana, Cuba, 27 August to 7 September 1990 ${ }^{14}$ Geneva Academy of International Humanitarian Law and Human Rights, Use of Force in Law Enforcement
and the Right to Life: the Role of the Human Rights Council (November, 2016), p 13.
} 
Nevertheless, the meaning of "imminent" has been interpreted by the Special Rapporteur on extrajudicial, summary or arbitrary executions to mean "a matter of seconds, not hours". ${ }^{15}$ That Special Rapporteur, Professor Christof Heyns, has ended his term, and now sits as a member of the HRC itself. As noted in a recent report on the use of lethal force by law enforcement, the meaning of "imminent" under Article 6 is a matter that "requires normative confirmation". ${ }^{16}$

\section{B. Abortion}

General Comment 36 addresses the topic of abortion in paragraph 8. The dominant theme of the paragraph concerns the protection of pregnant women from unsafe abortions. At no point does the HRC refer to any right to life for a foetus. Indeed, nothing in the General Comment clarifies when entitlement to the right commences, beyond the statement that it belongs to "all human beings" in paragraph 2 . The only point in the General Comment which relates to a right to life before birth concerns the explicit prohibition of the death penalty for pregnant women in Article 6(5) (see below). No comment is made, for example, about any general requirement for States to take measures to prevent harm to pregnant women which might cause the involuntary termination of her pregnancy. Hence, the implication from the General Comment is that Article 6 offers no protection to the unborn.

Paragraph 8 opens by noting that "States parties may adopt measures designed to regulate voluntary terminations of pregnancy". However, such measures must not violate the life of the pregnant woman, nor any other of her Covenant rights. The rest of the paragraph outlines that those restrictions on the regulation of abortion are extensive. Regarding the right to life of the pregnant woman, "States parties must provide safe, legal and effective access to abortion where the life and health of the pregnant woman or girl is at risk". Furthermore:

States parties may not regulate pregnancy or abortion in all other cases in a manner that runs contrary to their duty to ensure that women and girls do not have to undertake unsafe abortions, and they should revise their abortion laws accordingly. For example, they should not take measures such as criminalizing pregnancies by unmarried women or apply criminal sanctions against women and girls undergoing abortion or against medical service providers assisting them in doing so, since taking such measures compel women and girls to resort to unsafe abortion. States parties should not introduce new barriers and should remove existing barriers that deny effective access by women and girls to safe and legal abortion, including barriers caused as a result of the exercise of conscientious objection by individual medical providers. States parties should also effectively protect the lives of women and girls against the mental and physical health risks associated with unsafe abortions.... States parties should ensure the availability of, and effective access to, quality prenatal and post-abortion health care for women and girls, in all circumstances, and on a confidential basis. ${ }^{17}$

\footnotetext{
15 Report of the Special Rapporteur on extrajudicial, summary or arbitrary executions, Christof Heyns, A/ HRC/26/36, 1 April 2014, para 59.

${ }^{16}$ Geneva Academy of International Humanitarian Law and Human Rights, supra n 14, p 12.

17 States should also "prevent the stigmatisation of women and girls seeking abortion".
} 
Unsafe abortions threaten the lives of those who undergo them. The further necessary implication is that States must refrain from measures which effectively compel women to seek and undergo illegal abortions, which are notoriously unsafe because they are unregulated. Certainly, some restrictive measures are more likely than others to drive a woman to seek an unsafe abortion, such as prohibitions in even the most extreme of circumstances, such as when the foetus is unviable, or when it is conceived from rape or incest, or where the mother is a child. However, a law which distinguished severe from nonsevere circumstances, only prohibiting abortions in the latter situations, would still prompt women to seek unsafe abortions. "Countries with almost no deaths from unsafe abortion are those that allow abortion on request without restriction". ${ }^{18}$ The HRC agrees, hence it states, without apparent exceptions, that States should not criminalise abortion for either the person performing or the person having the abortion.

Furthermore, States are directed to remove barriers and not introduce new obstacles to rights of access to "safe and legal abortion", so barriers beyond criminalisation are also addressed. Such barriers would include bureaucratic obstacles such as a requirement of the consent of people beyond the mother, compulsory counselling, or further medical tests. ${ }^{19}$ Interestingly, there is no apparent concession by the HRC regarding restrictions on late term abortions, which are common amongst States. ${ }^{20}$

Having said that, the HRC's guidance here is obfuscated by its use of the word "should" in clarifying the measures to be taken as a result of the "duty" to ensure that States take measures to eradicate unsafe abortions.

General Comment 36 goes beyond the right to life of the pregnant woman, in basing further restrictions on a State's capacity to restrict access to abortion on other Covenant rights:

$[\mathrm{R}]$ estrictions on the ability of women or girls to seek abortion must not ... subject them to physical or mental pain or suffering which violates article 7 , discriminate against them or arbitrarily interfere with their privacy. ... States parties must provide safe, legal and effective access to abortion ... where carrying a pregnancy to term would cause the pregnant woman or girl substantial pain or suffering, most notably where the pregnancy is the result of rape or incest or is not viable.

In this General Comment, the HRC goes further than it has before in recognising a human right to have an abortion on request, though its substance can probably have been pieced together from the sum of its prior jurisprudence, including numerous Concluding Observations pursuant to State reports. Its decision in Mellet $v$ Ireland had previously established a right to an abortion in cases where the foetus was not viable. ${ }^{21}$ While there is apparently still scope for "regulation" of abortion, such regulation should not impose significant restrictions on a person's ability to access an abortion. Instead, regulation could

\footnotetext{
18 Marge Berer, “Abortion law and policy around the world: in search of decriminalisation”, (2017) 19 Health and Human Rights Journal 13, 15.

19 Berer, 18-19.

${ }^{20}$ Ibid., 23-24.

${ }^{21}$ Mellet v Ireland (2324/13), Views, CCPR/C/116/D/2324/2013, 17 December 2016.
} 
relate to the facilitation of access to safe abortions, such as through appropriate requirements regarding the credentials of abortion providers.

\section{Voluntary Dying}

The HRC has rarely addressed the issue of voluntary dying. There has been no Optional Protocol case on the matter, and it has issued only a few relevant comments on the matter in Concluding Observations. ${ }^{22}$ Paragraph 9 of General Comment 36 states:

While acknowledging the central importance to human dignity of personal autonomy, States should take adequate measures, without violating their other Covenant obligations, to prevent suicides, especially among individuals in particularly vulnerable situations, including individuals deprived of their liberty.

Even though Article 6 demands that States combat premature death, that does not mean that they should prohibit and punish suicide. Obviously, such a prohibition has limited utility. The punishment of a failed suicide attempt inflicts further distress on a vulnerable person, and almost certainly breaches rights regarding personal autonomy in Article 17 of the ICCPR. States are however prompted to take measures to dissuade people from suicide, or to prevent people from becoming suicidal. Such measures would include the funding of suicide prevention programmes like counselling and telephone "life lines". States have special obligations with regard to persons in detention (see below), who are particularly vulnerable to instances of suicide. Hence, States should take measures to reduce the opportunities for such people to commit suicide, such as the removal of fixtures which might enable a prisoner to hang themselves.

The HRC goes on at paragraph 9 to discuss voluntary assisted suicide:

States parties that allow medical professionals to provide medical treatment or the medical means in order to facilitate the termination of life of afflicted adults, such as the terminally ill, who experience severe physical or mental pain and suffering and wish to die with dignity, must ensure the existence of robust legal and institutional safeguards to verify that medical professionals are complying with the free, informed, explicit and, unambiguous decision of their patients, with a view to protecting patients from pressure and abuse.

Voluntary dying in such circumstances is often called voluntary assisted suicide or "euthanasia". A distinction is drawn between "active" euthanasia (where a person (often a medical professional) performs a positive act which causes someone to die (such as the injection of a lethal drug), and "passive" euthanasia (where a medical professional refrains from intervening to save a life). The latter practice is effectively legal in some circumstances: medical professionals do not have to provide life-saving treatment in every circumstance, especially where such treatment is only likely to prolong life for a short period of time, or where a person refuses treatment. The real controversy surrounds active euthanasia. Few States permit such a practice, though that number is growing. For example, the practice is legal in certain circumstances in the Netherlands, Belgium, Switzerland and Luxembourg, as

\footnotetext{
${ }^{22}$ See, eg, Human Rights Committee, Concluding Observations regarding Switzerland, 29 October 2009, $\mathrm{CCPR} / \mathrm{C} / \mathrm{CHE} / \mathrm{CO} / 3$, para 13 .
} 
well as some sub-State jurisdictions such as Oregon in the United States and Victoria in Australia.

The HRC confirms that the legalisation of "active euthanasia" is not per se a breach of the right to life. At a minimum, States must ensure that the person who is being assisted to die has made a truly voluntary decision. Interestingly, the HRC does not explicitly limit the article 6 compliance of assisted voluntary dying regimes to those with a terminal illness, as such instances are mentioned only as an example. Some States, such as Switzerland, permit access to assisted voluntary dying for people who do not have a terminal disease. ${ }^{23}$

Voluntary dying laws are applicable to minors in Belgium and the Netherlands. In 2001, regarding the Netherlands, the HRC had stated that it found it difficult "to reconcile a reasoned decision to terminate life with the evolving and maturing capacities of minors". ${ }^{24}$ Yet in General Comment 36, the HRC does not explicitly rule out Article 6 compliance when such regimes are applied to children with their consent. However, it is possible that the singling out of regimes regarding "afflicted adults" implies the non-compatibility with Article 6 for the application of such regimes to children.

\section{POSITIVE PROTECTION OF LIFE}

General Comment 36 provides that States must undertake positive actions to prevent unnecessary or premature deaths, as well as refrain from acts which arbitrarily deprive people of life.

\section{A. Non-State Actors}

The State must not only control its own agents with regard to the right to life; it must take measures to combat threats to life arising from non-state actors. Hence, it must adopt an appropriate criminal framework to address all forms of potentially deadly violence, including organized crime, family violence, honour killings, lynching, terrorism and hate crimes. ${ }^{25}$ Special protection measures should be adopted with regard to those who are especially vulnerable to deadly threats, such as human rights defenders, victims of family abuse, witnesses to crime, people with albinism in certain societies, and alleged witches. ${ }^{26}$ At paragraph 23, the HRC states:

States parties must respond urgently and effectively in order to protect individuals who find themselves under a specific threat, by adopting special measures such as the assignment of around-the-clock police protection, the issuance of protection and restraining orders against potential aggressors and, in exceptional cases, and only with the free and informed consent of the threatened individual, protective custody.

At paragraph 21, the HRC clarifies:

\footnotetext{
${ }^{23}$ For example, persons who have utilized Swiss suicide clinics include Sir Edward Downes, who wished to die with his terminally ill wife, and the Australian scientist David Goodall, who chose to die at the age of 104.

${ }^{24}$ Human Rights Committee, Concluding Observations regarding the Netherlands, 26 April 2001, UN doc $\mathrm{CCPR} / \mathrm{C} / 72 / \mathrm{NET}$, para $5(\mathrm{c})$.

25 General Comment 36, supra n 2, para 20.

${ }^{26}$ General Comment 36, supra n 2, para 23.
} 
States parties are ... under a due diligence obligation to undertake reasonable positive measures, which do not impose on them disproportionate burdens, in response to reasonably foreseeable threats to life originating from private persons and entities, whose conduct is not attributable to the State. Hence, States parties are obliged to take adequate preventive measures in order to protect individuals against reasonably foreseen threats of being murdered or killed by criminals and organized crime or militia groups, including armed or terrorist groups. States parties should also disband irregular armed groups, such as private armies and vigilante groups, that are responsible for deprivations of life and reduce the proliferation of potentially lethal weapons to unauthorized individuals. States parties must further take adequate measures of protection, including continuous supervision, in order to prevent, investigate, punish and remedy arbitrary deprivation of life by private entities, such as private transportation companies, private hospitals and private security firms. ${ }^{27}$

Hence, the HRC refrains from imposing an impossible or even disproportionate burden on States with regard to non-state threats to life. In doing so, it cites the Inter-American Court of Human Rights from Sawhoyamaxa Indigenous Community v Paraguay, which stated:

It is clear for the Court that a State cannot be responsible for all situations in which the right to life is at risk. Taking into account the difficulties involved in the planning and adoption of public policies and the operative choices that have to be made in view of the priorities and the resources available, the positive obligations of the State must be interpreted so that an impossible or disproportionate burden is not imposed upon the authorities. ${ }^{28}$

However, while the purported obligation here is softened by avoidance of disproportionate requirements, the due diligence requirement is couched as an obligation rather than a recommendation, apart from the reference to the disbanding of irregular armed groups. At that point in the paragraph, the HRC reverts to the softer language of "should". While the disbanding of such groups is no doubt difficult in some circumstances, it seems odd that the HRC should soften its language with regard to a phenomenon which is such an egregious threat to life.

States have special duties to protect the lives of persons within State custody. The duty extends to all "liberty-restricting State-run facilities" such as psychiatric facilities and refugee camps. Indeed, the HRC goes so far as to say that any unnatural loss of life in custody "creates a presumption" of a breach of Article 6, "which can only be rebutted by a proper investigation which establishes the State's compliance" therewith. ${ }^{29}$ These obligations have been confirmed before. ${ }^{30}$ However, the HRC takes them a step further in adding that "the

\footnotetext{
27 Similar duties are imposed on States with regard to threats to life "by other States, international organisations and foreign corporations", and with regard to lethal threats to people "subject to their jurisdiction ... outside their territory" at ibid., para 22.

28 Judgment of the Inter-American Court of Human Rights of 29 March 2006, para 155.

${ }^{29}$ General Comment 36, supra n 2, para 29.

${ }^{30}$ See, eg, Eshonov v Uzbekistan (1225/03), Views, CCPR/C/99/D/1225/2003, 18 August 2010.
} 
same heightened duty of care attaches to individuals held in private incarceration facilities operating pursuant to an authorization by the State". ${ }^{31}$

\section{B. Socio-economic aspects of the right to life}

The most radical part of General Comment 6 had been its extension of the right to life into the socio-economic arena, regarding which the HRC had stated:

the Committee considers that it would be desirable for States parties to take all possible measures to reduce infant mortality and to increase life expectancy, especially in adopting measures to eliminate malnutrition and epidemics. ${ }^{32}$

The inclusion of socio-economic aspects to the right is alluded to in paragraph 3 of General Comment 36, which confirms that Article 6 entails an "entitlement of individuals ... to enjoy a life with dignity". This notion of a "life with dignity" is not mentioned again until paragraph 26, which captures and expands far beyond the socio-economic aspects originally signaled in General Comment 6:

The duty to protect life also implies that States parties should take appropriate measures to address the general conditions in society that may give rise to direct threats to life or prevent individuals from enjoying their right to life with dignity. These general conditions may include high levels of criminal and gun violence, pervasive traffic and industrial accidents, degradation of the environment, deprivation of land, territories and resources of indigenous peoples, the prevalence of life threatening diseases, such as AIDS, tuberculosis or malaria, extensive substance abuse, widespread hunger and malnutrition and extreme poverty and homelessness.

The notion of a "dignified life" is linked to freedom from threats to life which arise from general societal conditions, whether driven by man-made and natural phenomena. The HRC goes on at paragraph 26 to outline how States address such societal conditions:

The measures called for addressing adequate conditions for protecting the right to life include, where necessary, measures designed to ensure access without delay by individuals to essential goods and services such as food, water, shelter, health-care, electricity and sanitation, and other measures designed to promote and facilitate adequate general conditions such as the bolstering of effective emergency health services, emergency response operations (including fire-fighters, ambulances and police forces) and social housing programs. States parties should also develop strategic plans for advancing the enjoyment of the right to life, which may comprise measures to fight the stigmatization associated with disabilities and diseases, including sexually transmitted diseases, which hamper access to medical care; detailed plans to promote education to non-violence; and campaigns for raising awareness of gender-based violence and harmful practices, and for improving access to medical examinations and treatments designed to reduce maternal and infant mortality. Furthermore, States parties should also develop, when necessary, contingency plans and disaster management plans designed to increase preparedness

\footnotetext{
31 General Comment 36, supra n 2, para 25.

32 General Comment 6, supra n 3, para 5.
} 
and address natural and man-made disasters, which may adversely affect enjoyment of the right to life, such as hurricanes, tsunamis, earthquakes, radio-active accidents and massive cyberattacks resulting in disruption of essential services.

This paragraph probably represents the most onerous of the suggested means of implementing Article 6, given the huge range of measures required in many fields of life, ranging from traffic management, occupation health and safety and health care to gun control and disaster preparedness. At the same time, it is arguably written in the language of aspiration, with the continuous use of the word "should" and other forms of soft language.

This paragraph highlights the permeability between the right to life and economic social and cultural rights. The latter rights are protected under the International Covenant on Economic Social and Cultural Rights (ICESCR). ${ }^{33}$ Such permeation between the two Covenants is now entrenched in the HRC's jurisprudence, though it may still cause consternation amongst States. A common objection to such permeation is that ICESCR obligations are progressive and subject to available resources under its obligation provision in Article 2(1). The comparative obligation in Article 2(1) the ICCPR does not afford such flexibility, dictating the immediate implementation of all obligations once the treaty comes into force for a State. ${ }^{34}$

It is arguable that paragraph 26 encapsulates much of the "minimum core" content of economic social and cultural rights identified under the ICESCR. These are obligations under that other Covenant which "ensure the satisfaction of, at the very least, minimum essential levels of each of the rights is incumbent upon every State party". ${ }^{35}$ Minimum core obligations differ from standard ICESCR obligations in that they are presumptively immediate obligations. ${ }^{36}$ The duties outlined in paragraph 26 of General Comment 36 seem likely to overlap considerably with those ICESCR minimum core obligations. The paragraph 26 obligations could be narrower, as they may only relate to matters that feasibly threaten life. Hence, the provision of "basic education" may be a minimum core obligation under the ICESCR $^{37}$ but perhaps not a relevant duty under Article 6, as a poor education does not generally threaten one's life.

However, it is unclear whether the reference in the General Comment to a "life with dignity" entails more than just living a life, but rather living a life above a certain standard. General Comment 36 refers to the obligation to address "direct threats to life" or to remove obstacles to the enjoyment of a right to life with dignity in paragraph 26, indicating two different obligations. The same allusion to a separate right to a life with dignity arises in

\footnotetext{
${ }^{33}$ International Covenant on Economic, Social and Cultural Rights1966, 993 UNTS 3

${ }^{34}$ See, for example, the Observations of the United States of America on the Human Rights Committee's Draft General Comment no 36 on Article 6: Right to Life, 6 October 2017, para 7, available via https://www.ohchr.org/EN/HRBodies/CCPR/Pages/GC36-Article6Righttolife.aspx [last accessed 29 January 2019].

${ }^{35}$ Committee on Economic Social and Cultural Rights (CESCR), General Comment 3, 1990, para 10.

${ }^{36}$ See John Tasioulas, "Minimum Core Obligations: Human Rights Obligations in the Here and Now", Research Paper, October, 2017, Commissioned by the Nordic Trust Fund and The World Bank, especially at Chapter 4.

${ }^{37}$ CESCR General Comment 3, supra n 35, para 10.
} 
paragraph 3, quoted above. The incorporation of a right to a dignified life within the right to life is found in certain domestic jurisdictions, such as India. ${ }^{38}$

Nevertheless, it seems doubtful that Article 6 itself includes a general right to live a life "with dignity", given that such a right can be found in the combination of a range of other human rights, including all others in the ICCPR, the ICESCR, and in the other core UN human rights treaties. In its comments on an earlier draft of General Comment 36, the government of Australia argued that:

not all human rights violations are connected to the right to life. Rather, each provision of the Covenant should be interpreted and applied independently. ${ }^{39}$

It is submitted that the preferable interpretation is that Article 6 addresses those circumstances which plausibly threaten one's life, and which simultaneously undermine dignity. There must be some link to a potentially deadly threat in order for Article 6 to be enlivened.

The issue of a "life with dignity" is referred to once more in General Comment 36 at paragraph 62:

Environmental degradation, climate change and unsustainable development constitute some of the most pressing and serious threats to the ability of present and future generations to enjoy the right to life. Obligations of States parties under international environmental law should thus inform the contents of article 6 of the Covenant ... Implementation of the obligation to respect and ensure the right to life, and in particular life with dignity, depends, inter alia, on measures taken by States parties to preserve the environment and protect it against harm, pollution and climate change caused by public and private actors. States parties should therefore ensure sustainable use of natural resources, develop and implement substantive environmental standards, conduct environmental impact assessments and consult with relevant States about activities likely to have a significant impact on the environment, provide notification to other States concerned about natural disasters and emergencies and cooperate with them, provide appropriate access to information on environmental hazards and pay due regard to the precautionary approach. (emphasis added)

The sources of harm mentioned in this paragraph pose potentially deadly threats to human beings, again indicating that a "life with dignity" is restricted to a right to live free from those threats that can potentially kill.

The possibility of Article 6 rights for future generations arose in EHP v Canada, an early Optional Protocol complaint about the dumping of nuclear waste in a particular locality: the HRC did not ultimately decide if such rights existed as the case was inadmissible due to a

\footnotetext{
${ }^{38}$ See, eg, the decision by the Supreme Court of India in Francis Coralie Mullin v The Administrator 1981, 2 SCR 516.

${ }^{39}$ Submission of the Australian Government: Draft General Comment No. 36 on Article 6 of the International Covenant on Civil and Political Rights: Right to life, para 6, available via https:/www.ohchr.org/EN/HRBodies/CCPR/Pages/GC36-Article6Righttolife.aspx [last accessed 29 January 2019].
} 
failure to exhaust local remedies. ${ }^{40}$ Paragraph 62 is the only mention in the General Comment of any requirement to take measures to protect the lives of future generations, though their apparently separate rights to lives with dignity may provide a clearer basis for these obligations. The references in this part of the General Comment are to international environmental instruments rather than $\mathrm{HRC}$ jurisprudence, and the paragraph arguably represents an extension of the scope of Article 6. Alternatively, it may signal its future development, as the language of this paragraph is soft with its use of the word "should".

\section{THE DEATH PENALTY}

The death penalty is prohibited for the 86 States that are party to the Second Optional Protocol to the ICCPR, which was adopted in 1989 and came into force in $1991 .{ }^{41}$ However, the death penalty is otherwise explicitly allowed in certain circumstances under Article 6. Article $6(2)$ reads:

In countries which have not abolished the death penalty, sentence of death may be imposed only for the most serious crimes in accordance with the law in force at the time of the commission of the crime and not contrary to the provisions of the present Covenant and to the Convention on the Prevention and Punishment of the Crime of Genocide. This penalty can only be carried out pursuant to a final judgement rendered by a competent court.

In General Comment 36, the HRC confirms its prior narrow interpretation of this provision by restricting its application only to those States that "have not abolished the death penalty". Hence, other States cannot benefit in any way from the exception, so for example they cannot reintroduce the death penalty. ${ }^{42}$ Nor can they extradite a person to a State that might charge the person with a capital crime in the absence of credible and effective assurances that the death penalty will not be imposed. ${ }^{43}$ The HRC takes that principle further in General Comment 36 at the end of paragraph 34:

In the same vein, the obligation not to reintroduce the death penalty for any specific crime requires States parties not to deport, extradite or otherwise transfer an individual to a country in which he or she is expected to stand trial for a capital offence, if the same offence does not carry the death penalty in the removing State, unless credible and effective assurances against exposing the individual to the death penalty have been obtained.

Not only is the death penalty exception narrow in terms of the States to which it applies: it is also narrow in terms of its scope for retentionist States. The HRC clarifies its prior decisions that the death penalty must never constitute a mandatory penalty. ${ }^{44}$ Furthermore,

\footnotetext{
${ }^{40}$ E.H.P. v Canada, 67/80, Admissibility, U.N. Doc. CCPR/C/OP/1 at 20 (1984), 27 October 1982.

41 Second Optional Protocol to the International Covenant on Civil and Political Rights (1989), A/RES/44/128

42 General Comment 36, supra n 2, para 34.

43 General Comment 36, supra n 2, para 34; see also Judge v Canada (829/98), Views, CCPR/C/78/D/829/1998, 13 August 2003.

44 General Comment 36, supra n 2, para 37. See also Thompson $v$ St Vincent and the Grenadines (806/98), Views, CCPR/C/70/D/806/1998, 18 October 2000.
} 
any death sentence imposed in contravention of the right to a fair trial in Article 14 breaches Article 6 as well. ${ }^{45}$ The death penalty must not be imposed in a discriminatory manner so it may not be disproportionately imposed upon racial, ethnic and other minorities including the indigent. ${ }^{46}$

The crucial definition of "most serious crimes" for the purposes of Article 6(2) is restricted only to "crimes of extreme gravity involving intentional killing". ${ }^{47}$ Furthermore:

a limited degree of involvement or of complicity in the commission of even the most serious crimes, such as providing the physical means for the commission of murder, cannot justify the imposition of the death penalty.

Hence, ancillary involvement in a murder does not count as a "most serious crime" which exposes a person to the death penalty. It is uncertain if this principle applies even to those who direct others to perpetrate a murder, such as an organized crime boss or the leader of a terrorist group.

The death penalty must be imposed with due regard for Article 7, the right to freedom from torture, inhuman and degrading treatment. Hence, certain methods of execution are prohibited. The HRC seems quite conservative at this point in the General Comment, given it does not single out common methods of execution as cruel, such as hanging, firing squad, lethal injection, and even beheading. ${ }^{48}$ It does, however, specify that injection with "untested lethal drugs" is prohibited. ${ }^{49}$ Numerous pharmaceutical manufacturers now prohibit the use of their drugs in executions. If this trend continues, it will become increasingly difficult to execute people with "tested" drugs. ${ }^{50}$

The HRC has not followed other courts, such as the European Court of Human Rights ${ }^{51}$ and the Judicial Committee of the Privy Council, ${ }^{52}$ in prohibiting protracted periods of time on death row prior to execution, known as the "death row phenomenon". The death row phenomenon has been found to constitute inhuman and degrading treatment by those courts, rather than a breach of the right to life, entailed in the mounting stress and anxiety as one waits for the grim appointment with a government executioner. In Johnson v Jamaica, the HRC declined to declare a long period of time on death row per se as a breach of the Covenant. ${ }^{53}$ Amongst other reasons, it did not want to adopt an approach which might

\footnotetext{
${ }^{45}$ General Comment 36, supra n 2, para 41.

${ }^{46}$ General Comment 36, supra n 2, para 44.

47 Ibid., para 35.

${ }^{48}$ Lethal injection was found not to breach the ICCPR in Cox $v$ Canada (539/93), Views, $\mathrm{CCPR} / \mathrm{C} / 52 / \mathrm{D} / 539 / 1993,31$ October 1994, at para 17.3.

${ }^{49}$ General Comment 36, supra n 2, para 40.

50 See, eg, Erin Dunne, "Drug companies opposed to the death penalty have changed executions", Washington Examiner, 14 August 2018.

${ }^{51}$ See Soering v UK, Merits, App No 14038/88 (Application No) A/161 (1989)

52 See Pratt and Morgan v Attorney-General for Jamaica [1993] 4 All ER 769.

53 Johnson v Jamaica (588/94), Views, CCPR/C/56/D/588/1994, 22 March 1996.
} 
encourage the swifter carrying out of death sentences. The HRC explains its contemporary approach to the issue at the end of paragraph 40:

Extreme delays in the implementation of a death penalty sentence, which exceed any reasonable period of time necessary to exhaust all legal remedies, may also entail the violation of article 7 of the Covenant, especially when the long time on death row exposes sentenced persons to harsh or stressful conditions, including, solitary confinement, and when they are particularly vulnerable due to factors such as age, health or mental state

The reference to delays "which exceed any reasonable period of time necessary" to pursue avenues of appeal or clemency may signal a deviation from Johnson. However, that statement is qualified by the use of the word "may", and the addition of the references to further aggravating factors in the rest of the quote.

At paragraph 43, the HRC again extends its prior jurisprudence with interesting comments regarding the burden of proof in capital trials, as well as after sentencing:

The execution of sentenced persons whose guilt has not been established beyond reasonable doubt also constitutes an arbitrary deprivation of life. States parties must therefore take all feasible measures in order to avoid wrongful convictions in death penalty cases, to review procedural barriers to reconsideration of convictions and to reexamine past convictions on the basis of new evidence, including new DNA evidence. States parties should also consider the implications for the evaluation of evidence presented in capital cases of new reliable studies, including studies suggesting the prevalence of false confessions and the unreliability of eyewitness testimony.

It is possible for an innocent person to be found guilty of a crime, even a capital crime, beyond a reasonable doubt and pursuant to a fair trial. This factor is presumably what led the late US Supreme Court Justice Antonin Scalia to state, notoriously:

This [Supreme] Court has never held that the [US] Constitution forbids the execution of a convicted defendant who has had a full and fair trial but is later able to convince a habeas court that he is 'actually' innocent. ${ }^{54}$

The HRC, in contrast, states that States must take all feasible measures to avoid execution of the innocent. Moreover, they "should" be prepared to reassess evidence in capital cases, presumably where a person continues to maintain their innocence, to ensure that only the guilty are executed.

The limitations on the death penalty exception confirmed by the HRC in General Comment 36 indicate that few if any death sentences imposed and carried out by States parties to the ICCPR will comply with the treaty. The lack of independent courts ${ }^{55}$ and a "general lack of fairness in the criminal process" 56 in many States parties deprive all death sentences in such States of ICCPR compliance. Death sentences for crimes short of murder,

\footnotetext{
${ }^{54}$ In re Troy Anthony Davis 557 US 952, 955, dissent of Antonin Scalia, 17 August 2009.

55 General Comment 36, supra n 2, paras 41 and 45 .

56 General Comment 36, supra n 2, para 41.
} 
such as drug trafficking, which are common in Asia, breach Article 6. Discriminatory application of the death penalty also breaches the ICCPR, and such is almost always present with regard to the indigent if not other minorities. ${ }^{57}$ Finally, few States assiduously revisit evidence after the conclusion of capital trials with the rigour suggested by the HRC, though that section of the General Comment is partly qualified by recommendatory rather than obligatory language.

The General Comment adds little to prior jurisprudence regarding the rights of all condemned prisoners to seek a pardon in Article 6(4), ${ }^{58}$ and the prohibition on the execution of pregnant women and people who were under the age of 18 at the time of the perpetration of a relevant capital crime in Article 6(5). ${ }^{59}$ The HRC does, however, purport to extend the range of persons who must not be sentenced to death at paragraph 49:

States parties must refrain from imposing the death penalty on individuals who face special barriers in defending themselves on an equal basis with others, such as persons whose serious psycho-social and intellectual disabilities impeded their effective defense, and on persons that have limited moral culpability. They should also refrain from executing persons that have diminished ability to understand the reasons for their sentence, and persons whose execution would be exceptionally cruel or would lead to exceptionally harsh results for them and their families, such as persons at an advanced age, parents to very young or dependent children, and individuals who have suffered in the past serious human rights violations.

Paragraph 49 closes the door further on the death penalty exception by extending the HRC's prior jurisprudence regarding persons exempt from the death penalty to those who have particular problems in defending themselves. With regard to the other listed categories, those with a diminished understanding of the reasons for sentence, the parents of young children and human rights victims, the language is qualified in that States "should" refrain from such executions.

Article 6(6) reads:

Nothing in this article shall be invoked to delay or to prevent the abolition of capital punishment by any State Party to the present Covenant.

The HRC expands upon that provision at paragraph 50:

Article 6, paragraph 6 reaffirms the position that States parties that are not yet totally abolitionist should be on an irrevocable path towards complete eradication of the death penalty, de facto and de jure, in the foreseeable future. The death penalty cannot be reconciled with full respect for the right to life, and abolition of the death penalty is both desirable and necessary for the enhancement of human dignity and progressive development of human rights. It is contrary to the object and purpose of article 6 for

\footnotetext{
57 The statistics gathered by the Death Penalty Information Center in the United States indicate that African Americans are overrepresented in terms of those executed: see https://deathpenaltyinfo.org/race-death-rowinmates-executed-1976\#defend (accessed 19 December 2018).

58 General Comment 36, supra n 2, para 47.

${ }^{59}$ General Comment 36, supra n 2, para 48.
} 
States parties to take steps to increase de facto the rate and extent in which they resort to the death penalty, or to reduce the number of pardons and commutations they grant.

The language of this paragraph begins with the soft "should" but escalates into harder obligatory language in its characterisation of an expansion in the application of the death penalty being "contrary to the object and purpose" of Article 6. Hence, a notable increase in a State's use of the death penalty, as for example occurred in Indonesia at the commencement of the term in 2015 of its current President, Joko Widodo, is contrary to Article 6(6). So too, apparently, is the reversal of a moratorium.

The HRC concludes its discussion of the death penalty at paragraph 51:

Although the allusion to the conditions for application of the death penalty in article 6 , paragraph 2 suggests that when drafting the Covenant the States parties did not universally regard the death penalty as a cruel, inhuman or degrading punishment per se, subsequent agreements by the States parties or subsequent practice establishing such agreements, may ultimately lead to the conclusion that the death penalty is contrary to article 7 of the Covenant under all circumstances. The increasing number of States parties to the Second Optional Protocol, as well as by other international instruments prohibiting the imposition or carrying out of the death penalty, and the growing number of nonabolitionist States that have nonetheless introduced a de facto moratorium on the exercise of the death penalty, suggest that considerable progress may have been made towards establishing an agreement among the States parties to consider the death penalty as a cruel, inhuman or degrading form of punishment. Such a legal development is consistent with the pro-abolitionist sprit of the Covenant, which manifests itself, inter alia, in the texts of article 6, paragraph 6 and the Second Optional Protocol.

The death penalty exception is a creature of the time of the ICCPR's adoption in 1966, when most States had the death penalty. The HRC here highlights the glaring anomaly, in light of contemporary standards, of a right to life provision that allows the death penalty. A similar exception was written into the right to life provision of the ECHR, Article 2, when it was adopted in 1951. Yet that instrument seems to have evolved so as to preclude the death penalty due its classification as a breach of its Article 3 (freedom from torture, inhuman cruel and degrading treatment) rather than Article $2 .{ }^{60}$ Indeed, it may be arguable that Article 2 itself has evolved due to state practice and later Protocols so as to prohibit the death penalty. ${ }^{61}$

Indeed, there is precedent for explicit ICCPR exceptions to evolve so as to no longer be applicable. Article 8 concerns the prohibition on slavery and, in paragraph 3, forced labour. Article 8(3)(c)(iii) states that the following is not to be interpreted as forced labour: "any service of a military character and, in countries where conscientious objection is recognized, any national service required by law of conscientious objectors" (emphasis added). It is clear

\footnotetext{
${ }^{60}$ Almost all parties to the ECHR are now parties to its Protocol 13 ETS 187 (2002), which precludes the death penalty in all circumstances. The European Court was influenced by this circumstance in stating in Al-Saadoon and Mufdhi v UK, Merits, 61498/08, 2 March 2010, at para 120, that the Court no longer considered the wording of Article 2 to be a bar on the possibility of interpreting the death penalty as a form of "inhuman or degrading treatment or punishment" for the purposes of Article 3.

${ }^{61}$ See Harris, O’Boyle, Bates, and Buckley, Harris, O’Boyle and Warbrick: Law of the European Convention on Human Rights, $4^{\text {th }}$ edn, (2018), 27 and 956
} 
that Article 8(c)(iii) contemplates the permissibility of regimes which do not permit conscientious objection to military service. Complaints in regard to such regimes were originally rejected by the HRC, largely due to the existence of Article 8(c)(iii). ${ }^{62}$ However, conscientious objection to compulsory military service has been recognized as a right under Article 18, the freedom of thought, conscience and religion, since the decision in Yoon and Choi $v$ Republic of Korea in 2007, ${ }^{63}$ despite the words of Article 8.

A similar evolution could take place with regard to the death penalty, such that it becomes recognized as a breach of Article 7 regardless of the provisions of Article 6. In any case, as noted, the strict interpretation of Article 6(2), 6(4), 6(5) and 6(6) indicate that very few if any executions in the world today comply with the ICCPR if they are conducted by States parties thereto.

\section{RELATIONSHIP OF ARTICLE 6 TO OTHER LEGAL REGIMES}

The last substantive part of the General Comment concerns the relationship between Article 6 and other human rights, as well as to other international legal regimes. I will focus on the latter. For example, paragraph 62 (reproduced above) discusses the relationship between Article 6 and international environmental law, especially that regarding climate change.

At paragraph 64, the HRC discusses the relationship between the right to life and the international laws of armed conflict:

Like the rest of the Covenant, article 6 continues to apply also in situations of armed conflict to which the rules of international humanitarian law are applicable, including to the conduct of hostilities. While rules of international humanitarian law may be relevant for the interpretation and application of article 6 when the situation calls for their application, both spheres of law are complementary, not mutually exclusive. Use of lethal force consistent with international humanitarian law and other applicable international law norms is, in general, not arbitrary.

Hence, the right to life continues to apply during times of armed conflict, but its scope is moulded by that circumstance. In particular, killings which take place in accordance with international humanitarian law ("IHL") are not "arbitrary", and therefore not in breach of Article 6. This reflects the decision of the International Court of Justice ("ICJ") in its Nuclear Weapons Opinion that international human rights law applies alongside IHL. In the rare case of conflict, IHL prevails as the lex specialis. ${ }^{64}$

The HRC goes on:

By contrast, practices inconsistent with international humanitarian law, entailing a risk to the lives of civilians and other persons protected by international humanitarian law, including the targeting of civilians, civilian objects and objects indispensable to

\footnotetext{
${ }^{62}$ L.T.K. v Finland (185/84), Admissibility, CCPR/C/OP/2 at 61 (1990), 9 July 1985.

${ }^{63}$ Yoon and Choi $v$ Republic of Korea (1231-1322/04), Views, CCPR/C/88/D/1321-1322/2004, 23 January 2007; see also Jeong et al $v$ Republic of Korea (1642-1741/07), Views, CCPR/C/101/D/1642-1741/2007, 27 April 2011.

${ }^{64}$ Legality of the Threat or Use of Nuclear Weapons, 1996 ICJ 226, 240.
} 
the survival of the civilian population, indiscriminate attacks, failure to apply the principles of precaution and proportionality, and the use of human shields, would also violate article 6 of the Covenant.

Killings in armed conflict in breach of IHL therefore breach Article 6. This statement again manifests a difference between the ICCPR and the ECHR insofar as they concern certain killings by a State party's military forces outside its territory. As explained above, extraterritorial obligations under the ECHR do not necessarily extend to the use of lethal force against persons if the State lacks prior physical control over those persons, ${ }^{65}$ even if the killings occur in breach of IHL.

In the same paragraph, the HRC adds:

States parties should, in general, disclose the criteria for attacking with lethal force individuals or objects whose targeting is expected to result in deprivation of life, including the legal basis for specific attacks, the process of identification of military targets and combatants or persons taking a direct part in hostilities, the circumstances in which relevant means and methods of warfare have been used, and whether less harmful alternatives were considered. They must also investigate alleged or suspected violations of article 6 in situations of armed conflict in accordance with the relevant international standards.

The HRC says that States parties "should" disclose whether "less harmful alternatives" are considered in terms of targeting and conducting warfare. However, there is no requirement under IHL to use the least amount of force possible in pursuing legitimate military objectives. ${ }^{66}$ This statement is emblematic of the occasional tendency of people within the international human rights field to presume to mould IHL, in defiance of the latter's status as lex specialis. ${ }^{67}$ Furthermore, the rules of engagement with regard to targeting and the use of lethal force will often be classified: it is very unlikely that States will share such information with the HRC. ${ }^{68}$

At paragraph 65, the HRC addresses the relationship between Article 6 and the development of weaponry.

States parties engaged in the deployment, use, sale or purchase of existing weapons and in the study, development, acquisition or adoption of weapons, and means or methods of warfare, must always consider their impact on the right to life.

\footnotetext{
65 Joseph and Dipnall, supra n 7, 123.

66 Yuval Shany, "Human Rights and Humanitarian Law as Competing Legal Paradigms for Fighting Terror", in Olga Ben-Naftali (ed), International Humanitarian Law and International Human Rights Law (OUP, 2011), 13 at 28 .

${ }^{67}$ Shany, supra n 66, 27-32, especially at 31. Shany was one of the HRC's Rapporteurs in drafting General Comment 36.

68 See Comments of the Netherlands to the Draft General Comment No 36 on Article 6 of the International Covenant on Civil and Political Rights, available via https://www.ohchr.org/EN/HRBodies/CCPR/Pages/GC36Article6Righttolife.aspx [last accessed 29 January 2019].
} 
It is unclear whether this statement demands more of States parties than what might exist under IHL or under other regimes related to weaponry. Almost any weapon can be used to kill. IHL prohibits indiscriminate weapons that cannot be used in a way that distinguishes between combatants, or legitimate targets, and civilians or civilian targets. Unnecessary suffering is also prohibited, which actually preferences weapons that are more immediately lethal than those that prolong suffering prior to death. The only weapons discussed specifically in paragraph 65 are lethal autonomous weapons, which do not apparently exist yet. The HRC, unsurprisingly, supports the view of the previous Special Rapporteur on extrajudicial, summary or arbitrary executions that such weapons should not be developed given that they lack human compassion and judgment, and raise difficult questions regarding accountability. ${ }^{69}$

Paragraph 66 addresses "the threat or use of weapons of mass destruction", including nuclear weapons. In General Comment 14, the HRC had stated:

The production, testing, possession, deployment and use of nuclear weapons should be prohibited and recognized as crimes against humanity. ${ }^{70}$

Paragraph 66 states:

The threat or use of weapons of mass destruction, in particular nuclear weapons, which are indiscriminate in effect and are of a nature to cause destruction of human life on a catastrophic scale is incompatible with respect for the right to life and may amount to a crime under international law. States parties must take all necessary measures to stop the proliferation of weapons of mass destruction, including measures to prevent their acquisition by non-state actors, to refrain from developing, producing, testing, acquiring, stockpiling, selling, transferring and using them, to destroy existing stockpiles, and to take adequate measures of protection against accidental use, all in accordance with their international obligations. They must also respect their international obligations to pursue in good faith negotiations in order to achieve the aim of nuclear disarmament under strict and effective international control and to afford adequate reparation to victims whose right to life has been or is being adversely affected by the testing or use of weapons of mass destruction, in accordance with principles of international responsibility.

Unlike that earlier General Comment, the HRC refrains from suggesting that the "possession" of such weapons be recognised as a crime against humanity. ${ }^{71}$ The closest it comes is its direction that States "destroy existing stockpiles ... in accordance with their international obligations", and to negotiate nuclear disarmament in good faith. The HRC here acknowledges that it goes beyond the Advisory Opinion of the ICJ in 1996 of the Nuclear Weapons case, where the ICJ majority could not conclude that the use or threat of use of nuclear weapons breached international law, including the ICCPR, in an "extreme circumstance of self-defence, in which the very survival of a State" was at stake. ${ }^{72}$ It is

\footnotetext{
${ }^{69}$ Report of the Special Rapporteur on extrajudicial, summary or arbitrary executions, A/HRC/23/47, 9 April 2013

${ }^{70}$ General Comment 14, supra n 4, para 7; see also paras 4-6.

71 See General Comment 14, supra n 4, para 6.

${ }^{72}$ See Legality of the Threat or Use of Nuclear Weapons, 1996 ICJ 226.
} 
possible that international law has evolved in the 22 years since that controversial advisory opinion.

Finally, the HRC confirms that acts of aggression, which breach international norms against the use of force, "violate ipso facto article 6". ${ }^{73}$

\section{CONCLUSION}

The General Comment is a valuable addition to the HRC's jurisprudence. General Comment 36 clarifies or extends its prior jurisprudence on the issues of abortion, voluntary dying, and its relationship with other legal regimes including international environmental law. It extends the socio-economic component of Article 6. However, the precise scope of that component remains unclear, especially the precise meaning of a right to a "life with dignity". The same is true of certain aspects of the circumstances in which law enforcement officers may use lethal force, especially regarding the issue of "imminence". On the death penalty exception, the HRC entrenches and extends its prior case law, to the point where it is doubtful whether there are any ICCPR-compliant executions by States parties. Finally, the HRC possibly overreaches regarding the linkages between Article 6 and IHL, ascribing too much of a role for the right in moulding IHL, rather than vice versa.

General Comment 36 represents a welcome embrace by the HRC of comparative jurisprudence on human rights. While most of the references contained therein are to its own jurisprudence, it includes numerous references amongst its 281 footnotes to other international material, including the jurisprudence of other UN treaty bodies, regional courts, special rapporteurs and other UN bodies. In contrast, its most recent prior General Comment, General Comment 35 adopted in 2014, contains few references beyond the HRC's own material in its 194 footnotes, and no regional references. ${ }^{74}$ General Comment 34, adopted in 2011, contains no references beyond HRC jurisprudence in its 117 footnotes. $^{75}$

HRC members have occasionally displayed an unfortunate isolationism. For example, in Yurich $v$ Chile, a minority stated that the HRC must "apply the Covenant, the whole Covenant and nothing but the Covenant". ${ }^{76}$ In contrast, the HRC in General Comment 36 applies the Covenant and a little more than the Covenant. It has used appropriate comparative and other UN material to fill gaps in its Article 6 cache. This approach facilitates the desirable development of consistent international human rights law across the globe.

\footnotetext{
${ }^{73}$ General Comment 36, supra n 2, para 70.

74 Human Rights Committee, General Comment 35: Article 9 (Liberty and Security of the Person), 16 December 2014.

75 Human Rights Committee, General Comment 34: Article 19: Freedoms of opinion and expression, 12 September 2011 .

${ }^{76}$ Yurich v Chile (1078/02), CCPR/C/85/D/1078/2002, 12 December 2005, dissenting opinion of Ms Chanet et al.
} 